\title{
Alchemy in Russian Literature
}

\author{
Hamlet Isakhanli \\ Khazar University, Baku, Azerbaijan \\ hamlet@khazar.org
}

\begin{abstract}
Along with sciences, alchemical activity heavily influenced literature and art, and the images of alchemists were widely reflected in the works of poets, writers, artists, philosophers and scientists. In Eastern and Western literature of ancient, medieval, and modern times, alchemy, together with the intriguing images of alchemists, was used also as a source of vivid metaphors.

This article is devoted to the subject of alchemy in Russian literature, investigating which writers were interested in it and how it was developed in Russia. Prominent Russian authors' poetic and prosaic writings have been perused throughout the research paper and it is believed that the images of alchemists portrayed by Alexander Pushkin, Nikolai Gogol, Alexander Herzen, Nikolai Ogarev, Alexei Tolstoy, and Mikhail Bulgakov were of European origin.
\end{abstract}

Keywords: alchemy, metal transmutation, science and alchemy in Russia, Russian literature, Pushkin, A. Tolstoy, M. Bulgakov.

\section{Introduction}

Using the word alchemy brings several sorts of activities from the ancient times to one's mind. One of those pursuits is metal transmutation - transmuting a base metal into a noble one, i.e. into silver or gold. Starting from very prominent scientists to swindlers, many people were involved in this very activity. Gradually, there was forming the idea of the existence of a secret substance named elixir (in Arabic aliksir) and that substance would transmute metals into silver, and later, into gold. That secret and mysterious substance took the name "philosopher's stone" afterwards. The idea of human immortality was another desired target of alchemists, yet as natural it was as ancient. At least, rejuvenation and by this way living a longer and healthier life was one of the foremost dreams. They related it to preparing a mysterious substance. Even, maybe, it would be possible to obtain such an elixir for both transmuting metals into gold and rejuvenating human beings and turning them into immortals. Along with these two directions of endeavours stemming from 
prodigious dreams, there was also applied chemical activities which targeted daily needs and dealt with making useful substances (dye, perfume, medication, and poison). Metal transmutation and preparation of useful substances were ancient leading fields of the development period of chemistry. All these activities received the name "alchemy" (al - is the definite article in Arabic) in the meanwhile of the flourishment of Islamic science and culture.

The passion for gold, rejuvenation, and immortality made the alchemy very popular. Poets, philosophers, musicians, and artists talked about alchemy, created romantic and cunning alchemist characters, adopted the word alchemy as a metaphor. Alchemy existed in the literature and art in Ancient Egypt and Mesopotomia, China, Islamic world, and eventually, in Europe. Alchemy gave a motif and metaphor to the art and in its turn, the art did not remain beholden and it glorified the alchemy.

The alchemy in literature and art has been studied, plenty of articles and books have been published on it. Nevertheless, almost most of those researches and publications entirely focus on European literature. The topic of alchemy has been touched upon in the works of a lot of poets and writers, such as Dante Alighieri, Geoffrey Chaucer, Desiderius Erasmus, Ben Jonson, William Shakespeare, John Donne, Jonathan Swift, Mary Shelley, Goethe, Victor Hugo, Gabriel Garcia Marquez, and Paulo Coelho (e.g., see: Isaxanli, 2018, pp. 298-299).

1. Holmyard, E. J. Alchemy.

2. Read, J. The Alchemist in Life, Literature and Art, 1997 (first published in 1947)

3. Meakin, D. Hermetic Fictions: Alchemy and Irony in the Novel, 1995.

4. Ziolkowski, T. Alchemist in Literature: From Dante to the Present, 2015.

5. Hutin, S. Les Alchemistes au Moyen Age, 1995.

6. Lenner, J. van. Art et alchemic, 1966.

7. Roberth, G. The Mirror of Alchemy: Alchemical Ideas and Images in Manuscripts and Books from Antiquity to the Seventeenth Century, 1994.

8. Szulakowska, U. Alchemy in Contemporary Art, 2011.

9. Lambert, A. The Heritage of Hermetic Alchemy in Contemporary British Literature, 2004.

10. Pinkus, K. Alchemical Mercury. A Theory of Ambivalence, 2010. 
11. Linden, S. J. Darke Hierogliphicks: Alchemy in English Literature from Chaucer to the Restoration, 1996.

Alchemy also developed in the Islamic world. Prominent scientists like Jabir ibn Hayyan and Abu Bakr al-Razi raised the alchemy to scientific level. Alchemy was a popular topic of Eastern literature. Though, for some reason, this topic has not been investigated until recently. The author of this research is as well the author of a comprehensive research in this specific area (Isaxanli, 2018; Isakhanli, 2020).

This research paper is dedicated to the alchemy in Russian literature. Likewise the Eastern literature, alchemy in Russian literature and, in general, the subject of alchemy in Russia has not been studied in-depth (perhaps it is right to say: not studied at all). Did the rich Russian literature bring the alchemy subject up? Does the alchemy in Russian literature stem from "inside" or from Europe? The science in Russia delayed in development, so did alchemy. In this research paper, it has been attempted to clarify this issue by firstly discussing A. S. Pushkin. Subsequently, there has been talked about other Russian poets and writers who portrayed directly or indirectly an alchemical activity or an alchemist in their works. The alchemy line of the writings of Pushkin and Gogol, Herzen and Ogarev, A. Tolstoy and Bulgakov has been examined.

\section{Science in Russia. Why Did Alchemy Not Develop in Time?}

From the 12 th to the 18 th centuries, there was no alchemy in Russia, nor was there scientific work of this kind taking place in Latin Europe. Why was this the case?

Alexander Pushkin, the great Russian poet and sophisticated thinker, in an article titled The Misery of Russian Literature (Pushkin, 1976, pp. 360-366) wrote that his country, which had adopted Christianity from Byzantium was, for a long period, estranged from Europe and did not participate in any of Europe's political or intellectual advances. He said that neither the useful awakening shock delivered to Europe by the crusades, nor the Renaissance, had any resonance in Russia. The great poet claimed that the Russia's supreme contribution was to halt the Mongol invasion, because the Mongols were afraid to have Russia at their backs in an attack on Europe, and thus Europe was saved.

Amongst Pushkin's more popular aphorisms was the following: "The Tatars were not like the Moors. In conquering Russia, they granted her neither algebra nor Aristotle". Consequently, the poet saw the main reason for Russia's lagging behind Europe as the less advanced Mongols' occupation of Russia and not Europe. 
Although he began the article with a rational explanation, he did not follow through to the end. The point is that the Europeans began to translate and adopt algebra as well as the various sciences and philosophy, including Aristotle, from Arabic in the 12th-13th centuries (with minor works in the 11th century); before that they were not ready to do so. Apparently, the Russians were not mature enough for the intellectual challenges of the 12th-13th centuries, when the Europeans were active. This being so, the Mongols could not have been responsible for holding Russians back, on the contrary, they taught the Russians an effective administrative system and financial policy. The problem was with the Russians themselves and the tide of history. Pushkin himself touched on the issue in his article, pointing to the time that Europe did have a positive effect: "Finally, Peter (the Great - H.I.) appeared ... The European enlightenment reached the conquered Neva coast" (Pushkin, 1976, p. 361). Russians began to study science and philosophy not directly from the Islamic world, but with considerably delay via Europe.

Pushkin's idea that the Mongols did not attack Europe because they were wary of Russia, so Europe was rescued by Russians, is not supported by objective historiography (Halperin, 1987; Vernadskiy, 2004). The Mongols were not weakened by war with the Russians; after victories over the Kipchaks and Russians, they defeated the Polish, Hungarian and Croatian armies without too much difficulty, and approached Vienna. However, the Mongols did not launch a large-scale attack on Central and Western Europe, and the reasons were, firstly, the death of the great khan Ogedei (December 11, 1241) and the struggle for power between members of the ruling dynasty, and then, most likely, the death of Batu Khan.

Alchemy found its way into Russian literature of the 19th-20th centuries. The image of the alchemist created by Russian writers (Pushkin, Gogol, Ogarev) had two features: they were Europeans (Russia was not familiar with alchemy), and they were passionate about their search rather than burning with a desire for riches. According to Herzen, alchemy was far from realistic, it stood alongside magic, with a language well-known to those skilled in the work, and was the opposite of the true science of physics. Nikolay Dobrolyubov and other writer-politicians of the time used a similar alchemical language. Alexei Tolstoy's alchemist (European) hero is a romantic wayfarer. Bulgakov recalled alchemists with a rejuvenating elixir, makers of counterfeit money, ideas of a homunculus and other fantasies. Chekhov's protagonist - a sister - tells her brother that he is occupied with useless, idle work and calls him an alchemist: "You spend your best years on God knows what. As an alchemist, you dig into old, useless junk" (Chekhov, 1976, pp. 413-423). 


\section{The Alchemy of Pushkin and Gogol}

The great Russian poet Alexander Pushkin (1799-1837) created great works in all literary genres (poetry, verse novel, prose and drama), conducted historical research and kept an eye open for world events in literature, science and art. Nicholas I of Russia (1796-1855) said, after a conversation with Pushkin: "I have just talked to the smartest man in Russia" (Volkov, 1989, p. 210; Eidelmann, 1987, p. 53). Pushkin produced a story line dedicated to alchemy in an unfinished work in 1835. A while later, after his death, it was brought to light in the journal Sovremennik (Contemporary) (Pushkin, 1837, pp. 193-224); the editorial board titled it, Scenes from the Times of Knights (Сцены из рыцарских времен). Pushkin began writing it as poetry, but then turned to prose with some verse.

The events take place somewhere in medieval Europe. Franz, a young poet, uninterested in his inheritance and money, is termed a 'spiritual knight' and he crosses paths with his neighbour, the alchemist Berthold.

Berthold is looking for money for his next, possibly final alchemical experiment, to produce gold; Franz's narrow-minded father, derides the alchemist's (Berthold's) habitually frenetic and impoverished lifestyle: "If you had not thrown all the money that passed through your hands into the alchemical fire, you would be rich now". Berthold replies as a real man of science: "I do not need gold; I am in search of truth". Their dialogue continues, "If your experiment worked out and you had gold and glory in abundance, would you enjoy a quiet life?" The answer indicates an endless passion for scientific search: "I will engage in further research - I think there is a way to invent perpetuum mobile... If I find perpetual motion, then I see no limits to human creativity ..."

Franz is engrossed in thoughts about how to see his beautiful grandee lover, and he thinks how to watch a knights' contest taking place in the castle at which he could get close to his love. He is imprisoned as the result of rebellious attempts against Count Rothenfield, derived from hopeless love, jealousy, "spiritual knighthood" and seeking vengeance. Franz has been sentenced to life in the castle (in Rothenfield's words): "He will not come out until the walls of my castle rise into the air and fly away" (Pushkin, 1960, p. 430).

Pushkin also planned for alchemist Berthold to be imprisoned in the same castle in his incomplete work. As a prototype for Berthold, he had used the legendary alchemist Berthold Schwarz. There is no definitive information about when this alchemist lived, if indeed he ever did. According to legend, this man, usually considered to be German, invented black gunpowder in Europe; it seems more likely that he only described a method of producing it. The way that black gunpowder 
reached Europe from China via the Mongols and Islam has been discussed above. Again, according to legend, he was arrested and, while in prison, he continued his alchemical work and accidentally produced gunpowder (Feldhaus, 1910, pp. 617$619)$.

Pushkin planned that Berthold and Franz, while in jail, prepared gunpowder and exploded it. Consequently, as Rothenfeld himself had said, the walls of the castle were blown up, and the prisoners were free. In Pushkin's plan, Faust and Mephistopheles would arrive and the latter (supposedly the inventor of book printing) would advise prioritising the printing machine rather than cannon and guns.

Russian writer Nikolai Gogol (1809-1852) scrutinised carefully the activities of the alchemist, giving a brief and vivid description of his residence, hopes and desires: "Imagine a medieval city in Germany; narrow, curved streets; lofty, varicoloured gothic buildings and, among them, some old, half wrecked, desolate place with tightly nailed windows, with cracked walls covered in moss and senility - this is the habitation of the alchemists. There is no sign of a presence or life. But in the silent night, the bluish smoke coming out of the chimney tells of the vigilance of the old man who had not yet abandoned hope, even though the seeking had greyed his hair. The devout craftsman of the Middle Ages presumes that ghosts have settled there and being frightened, runs away from that dwelling. In fact, rather than apparitions, an irresistible curiosity to know and a desire that lives only for itself, inexpungible, self-fuelled and inflamed by misfortune, are settled there. Penetrating the secrets of human cognition, the Inquisition persecutes in vain the initial natural power of the European spirit: this power resists and enrobed in fear, plunges into its affairs with greater pleasure" (Gogol, 1952, p. 24).

\section{Herzen, Ogarev and Alchemy}

Alexandr Herzen (1812-1870) spent the first part of his life in Russia, the second part (after 1847) in Europe. Herzen had a university education in physicsmathematics-astronomy, was recognized as a philosopher of politics, a journalist and writer, and was a herald of socialism. In his first article, published under the pseudonym Iskander (Alexander in Islamic countries) in 1836 and dedicated to the writer E. T. A. Hoffmann, he touched upon the image of the "sand man" created by Hoffmann's boundless fantasy: "one day appears as an alchemist ..." (Herzen, 1962, p. 50).

In his writing, Herzen addressed the ideas of alchemy and the image of the alchemist several times. For his knowledge of alchemy, he was beholden to his general reading 
and probably also to his cousin Alexey Yakovlev, who was nicknamed Chemist. Alexey was known for his obsession with alchemy: "Passionately involved in alchemy, he lived an ascetic life, occupying only one room in his large Moscow house. From morning till evening, like a medieval alchemist, he mixed things in the retorts, set fire, blew up, and the robe, he always wore, burned and full of reagents, was the best proof of his diligence. In Moscow, he was known as an eccentric ..." (Belorukov, 2018).

Herzen's book of essays From the Other Shore (in German: Vom anderen Ufer, Hamburg, 1850; in Russian: С того берега, London, 1855), made his name as a writer. It offered a critique of Western civilizations, saying that people did not like what was simple, did not accept nature as it was and were too absorbed in ill-fated dreams. Explaining these thoughts, he confronted physics with alchemy, describing the first positively and siding the latter with magic, as removed from reality: "Physics presents us with its independent identity, whereas we fancy alchemy as magic; but life and nature follow their own paths indifferently" (Novikova \& Sizemskaya, 1996, p. 171).

Herzen recalls in his Dilettantism in Science that many people, including "practitioners and mystics", did not like science, saying that they did not understand science in alchemical language. He presents his version of their thinking: "... If those who are knowledgeable in science do not understand it, then who is science for? Hence, does science, like alchemy, exist for only its adepts, who have the key to its hieroglyphic language?". Dilettantes love to make "simple philosophy", as distinct from scientists they "love science, but just do not work on science", "they wish for a "light science" and "intangible speculations" do not hit home with these dilettantes (the First Article, see: Herzen, 1954, p. 12).

In his seventh letter, Bacon and his School in England from his book Letters on the Study of Nature he wrote "Bacon brought luck, and progress started in the physical sciences". Further on, he levels criticism at "minds distorted by scholasticism, distracted people, those who study life from books, ascetics", and suggests (many times in these and other works) that the knowledge they gained served their ambition for authority, like a theologian scholar, the alchemist "Claude Frollo's gentle feeling of love was turning into a poisonous taint" in Victor Hugo's Notre-Dame de Paris. Herzen, who appeared to be unaware of Bacon's alchemical activities, in the manner intrinsic to his other works, refers to alchemy and alchemists as examples of antiscience, anti-scientist: "Look at the alchemist before his furnace - this man, surrounded by magical signs and awful instruments, why the pallor in his cheeks, this convulsive look and this kind of tremulous breath? Because, in this man, there is no agape, no love for the truth, but lustful torture, violence; because he is making 
gold, a homunculus in the retort (Herzen, 1985, p. 364; Herzen, 1954, p. 256). In his third epistle, Greek Philosophy, Herzen again rips into an alchemist: "In the ugly form of medieval alchemy,... having a tendency towards self-admiration, the adept was superior to the Greek, the alchemist considered himself the key to the truth" (Herzen, 1954, p. 256).

Note. Herzen became more popular with his book of artistic memories, My Past and Thoughts (Былое и думы), reflecting the views of his age and, partially, with the novel Who is to Blame? (Кто виноват?) which proposes that happiness is impossible without public interest.

Note. Herzen changed from the 'Westerner' who loved Russia to the socialist who criticized the West. At the same time, he did not have a good relationship with Marx and Engels; "And this misunderstanding was mutual" (Livshitz, 1957).

Russian poet and publicist Nikolai Ogarev (1813-1877) in his poem Alchemist (1867) expertly expresses the "gray-haired monk's" dedication to his work, the "promise of the alchemist to live for science and reject love and pleasure", the one who desires to make gold and on his journey "does not look for money or praise, ... who wants to feel the pulse of nature..." on the other hand he shows his disappointment at the next failure (Ogarev, 1956, p. 49). Ogarev and Herzen were friends from childhood.

\section{The Alchemical Protagonist of Aleksey Tolstoy}

Count Aleksey Konstantinovich Tolstoy (1817 - 1875) was a Russian writer who was on familiar terms with the Tsar's palace and was a prominent representative of Russian romanticism. He traveled in Europe during his childhood and youth, as well as in his advanced years, and studied, lived and worked there. The subject of Tolstoy's unfinished Alchemist poem was taken from the legend of Ramon Lully (although the author does not mention Lully's name, he presents his hero as Alchemist) (Tolstoy, 1984, p. 245).

Lully, in legend a woman chaser, is riding across a square in the city of Palma (Majorca) where he was born, when he sees a beautiful woman entering a church; losing his mind the alchemist follows her into the church on his horse. As the sound of the choir and organ die down, the horse's hoofbeats are heard and the "delirious cavalier" appears. Who is that - an Egyptian, Moroccan, Granadan or Tunisian? No, 
his clothing shows that he is a Spanish knight. The knight approaches and, addressing the woman as "mistress of my mind", announces that he "prefers love to a place in paradise", and adds, "my mind, my life, my dignity and my sword are at your feet, senora" and insists, "send me on the most perilous journey to win your love". When she sees that he will not desist (who knows?), she answers, "I am ready to share your passion", but "we must obtain immortality", "acquire a miraculous root, return to me and I will be yours for eternity". The knight sails to distant lands in search of "Solomon's seal" and the "fascinating Trismegistus stone" (Tolstoy, 1984, p. 245).

\section{The Alchemy of Mikhail Bulgakov}

Prominent Russian writer Mikhail Bulgakov (1891-1940) had a difficult life and suffered censorship during his an intensively creative life. He had an interest in occultism; there were rumours that he was an occultist, but many people reject the idea. He wrote his last and the most famous novel Master and Margarita while ill and having failing eyesight, in the main dictating to his wife Elena. The work was unfinished and was not published until after his death, in 1966. Combining Soviet reality and fantasy, it has been adapted for the screen in different countries (Varlamov, 2008).

"Master and Margarita" has three main story lines - the doings of a devilish team of three people and a speaking cat led by Satan (Woland - one of the names of the devil in Goethe's Faust); the Soviet (Moscow) literary elite and theatre life; and a novel written by a writer referred to only as the Master about Yeshua and Pontius Pilate, the Roman prefect of Judaea (Bulgakov, 1984). I will only comment briefly here on events related to alchemy.

Woland's aide gives to Margarita - Master's devoted lover - a yellowish, oily cream (elixir) in a golden box. After Margarita applies the cream to her face and body her wrinkles disappear, her muscles tighten up, she loses weight, is rejuvenated and, full of happiness, begins to shine. Given the ability to fly, Margarita becomes the hostess of a 'majestic ball' organized by Woland (Bulgakov, 1984, Chap. 23). She meets many famous people in the ballroom: Johann Strauss, conductor of the orchestra; 'the wizard alchemist emperor Rudolf' who supported alchemists; "handsome, black-haired Monsieur Jacques with tail-coat and shoes, a firm believer, maker of counterfeit money, state traitor, however, a good alchemist who became famous for poisoning the mistress of the King".

Jacques Coeur (1395/1400? -1456), the prototype of Bulgakov's alchemist character Jacques, was a well-known, rich French merchant. Coeur ruled and managed an 
important part of France's trade relations with Muslim countries and gained considerable financial standing as well as access to the palace of Charles VII. But he was later arrested and accused of counterfeiting money and poisoning the mistress of the King, the stunning beauty Agnès Sorel (1422-1450). Finally, he was released from prison and went to Rome, where he was well received. He was later sent to help the Greeks fighting the Turks and died there. It is said that Jacques was innocent of the charges but was the victim of slanders spread by people jealous of his fortune. More recent investigations show that Agnès was poisoned by mercury... (Heers, 2013).

Although Woland reminds one of Mephistopheles, he is also different from him, seemingly 'more humane'. Sending them off to eternal peace, he says goodbye to the Master and Margarita, adding: "Wouldn't you like to sit alongside a retort, like Faust, in the hope of creating a new homunculus?" (Bulgakov, 1984, Chap. 32, pp. 437-438).

\section{Conclusion}

The alchemy subject entered the Russian literature from Europe. Even the alchemist characters in Russian literature are not Russians, but Western Europeans. The prototype of Pushkin's Berthold was the legendary alchemist Berthold Schwarz. Gogol described the hopes and dreams of the alchemist in Germany. Herzen recalled Claude Frollo, the alchemist character of V. Hugo's Notre-Dame de Paris (The Hunchback of Notre Dame). The prototype of the romantic alchemist character created by A. Tolstoy was Ramon Lully (even he did not tell it explicitly). Woland played an important role in Master and Margarita, where Bulgakov described the early years of the Soviets. Even though he reminded of Mephistopheles, he had unlike features. The prototype of another alchemist Jacques, described by Bulgakov, was also famous - rich French merchant Jacques Coeur.

\section{References}

Belorukov, D. F., 2018. Костромская вотчина А. И. Гериена [Kostromskaya votchina A. I. Herzena]. s.l.:Public Cultural Fund of Kostroma.

Bulgakov, M. A., 1984. Macmep u Mapzapuma [Master and Margarita]. Moscow: Vekhi.

Chekhov, А. P., 1976. Собрание сочинений в 18 томах. Том 5 'Рассказы, юморески' [Collected works in 18 Volumes. Volume 5 'Stories and Humoresque']. Moscow: Nauka.

Eidelmann, N. Y., 1987. Пушкин. Из биографии и творчества [Pushkin. From Biography and Oeuvre]. Moscow: Khudojestvennaya literatura. 
Feldhaus, F. M., 1910. Berthold (Erfinder des Schießpulvers). Allgemeine Deutsche Biographie, Volume 55, p. 617-619.

Gogol, N. V., 1952. Полное собрание сочинений в 14 томах. Том 8 'Статьи из Aрабесок' [Full Collected Works in 14 Volumes. Volume 8 'Arabeski Articles']. Moscow: Izdatelstvo AN USSR.

Halperin, C. J., 1987. Russia and the Golden Horde. The Mongol Impact on Medieval Russian History. Bloomington: Indiana University Press.

Heers, J., 2013. Jacques Coeur, 1400-1456. Paris: Perrin.

Herzen, A. I., 1985. Ends and Beginnings. s.1.:Oxford Paperbacks.

Herzen, A. I., 1954. Собрание сочинений в 30-ти томах. Том 3: Дилетантизм в науке [Collected Works in 30 Volumes. Volume 3: Dilletantism in Science]. Moscow: AN USSR.

Herzen, A. I., 1962. О литераmype [On Literature]. Moscow: State Publishing house of fine literature.

Isaxanli, H., 2018. Olkimya: Elm, sanət va mistika [Alchemy: Science, Art and Mysticism]. 1st ed. Baku: Khazar University Press.

Isakhanli, H., 2020. Alchemy in Eastern Literature. Khazar Journal of Humanities and Social Sciences., 23(1), pp. 22-47. DOI: 10.5782/2223-2621.2020.23.1.22

Livshitz, М. А. 1957. К. Маркс и Ф. Энгельс об искусстве [К. Marx and F. Engels on Art]. Moscow: Iskusstvo.

Novikova, L. I. \& Sizemskaya, I. N. 1996. Очерки русской философии. Антология [Essays on Russian Philosophy. Anthology]. Moscow: IFRAN

Ogarev, N. P., 1956. Стихотворения и поэмы [Verses and poems]. Leningrad: Sovetskiy Pisatel.

Pushkin, A. S., 1837. 'Сцены из Рыцарских Времен' [Scenes from the Times of Knights]. Современник: литературный и политический журнал [Sovremennik: Literary and Policy Journal], 2(5), pp. 193-224.

Pushkin, A. S., 1960. Собрание Сочинений в 10 томах. Том 4 Сиены из Рыцарских Времен [Collected Works in 10 Volumes. Volume 4 Scenes from the Times of Knights]. Moscow: Gossudarstvennoe Izdatelstvo Khudojestvennoi Literatury.

Pushkin, A. S., 1976. Собрание Сочинений в 10 томах. Том 6 Критика и публицистика [Collected Works in 10 Volumes. Volume 6 Critics and Publicistic Writing]. Moscow: Khudojestvennaya Literatura.

Tolstoy, А., 1984. Сочинения в 2-х томах, том 1 [Works in 2 Volumes. Volume 1]. Moscow: Sovetskiy Pisatel.

Varlamov, A. N., 2008. Михаил Булгаков. Биография (в 2 m.) [Mikhail Bulgakov. Biography in 2 Volumes]. St. Petersburg: Vita Nova.

Vernadskiy, G. V., 2004. Монголье и Pусь [Mongols and Ancient Rus]. Moscow: LeanAgraf.

Volkov, G. N., 1989. Мир Пушкина: личность, мировоззрение, окружение [Pushkin's World: personality, mindset, environment]. Moscow: Molodaya Gvardiya. 